\title{
Issue salience (Public Diplomacy) (see also theme or media coverage salience)
}

\section{AUTHOR}

Sarah Marschlich

\section{KEYWORDS}

public diplomacy, issue salience, agenda-setting, foreign publics, governmental communication, international news broadcasting

\section{BRIEF DESCRIPTION}

The variable "issue salience" refers to the visibility or prominence of a given topic or theme occurring in the news coverage and is used to explore first-level agenda-setting (McCombs \& Shaw, 1972). In addition to actor salience and valence, issue salience is analyzed to describe and explore the news coverage on different events and public debates. Mostly, issue salience is measured as the number of mentioning a particular issue, topic, or theme.

\section{FIELD OF APPLICATION/THEORETICAL FOUNDATION}

Issue salience is analyzed using content analysis across different subfields of communication and media research, including the field of public diplomacy. In public diplomacy research, scholars measure issue salience in the context of governmental communication on their official channels online and offline or the representation of countries in social or mass media. Researchers embed the concept of issue salience primarily in agenda-setting theory (McCombs \& Shaw, 1972), analyzing it as an independent variable from which to derive implications of news media coverage on audiences' perceptions on a certain object or examining the relationship between issue salience in the media and the public agenda.

\begin{abstract}
REFERENCES/COMBINATION WITH OTHER METHODS OF DATA COLLECTION

When it comes to analyses on issue salience and its link to public perceptions, a mixed-method study design incorporating content analysis in combination with surveys is used to validate issue salience.
\end{abstract}

\section{EXAMPLE STUDY}

Zhou et al., (2013)

\section{INFORMATION ON ZHOU ET AL., 2013}

Authors: Zhang et al.

Research question/research interest: Comparison between news coverage on Great Britain (in terms of themes) in U.S.-American and Chinese news media during the Olympic Games 2012 RQ: What were the most salient themes in British, U.S., and Chinese media when they covered the opening ceremony of the London Olympics? Object of analysis: Newspaper (30 media outlets across three countries (the United States, the United Kingdom, and China, not explicated)

Time frame of analysis: 24 July 2012 to 12 August 2012

\section{INFORMATION ABOUT VARIABLE}

Variable name/definition: Media coverage salience: Number of mentions given to a particular theme

Level of analysis: Story

Values:

(1) Countryside (e.g., emphasis of British natural beauty and scenic sites)

(2) Creativity (e.g., focus on British creative sector, such as arts, film, and literature)

(3) Entrepreneurship (e.g., portrayals on entrepreneurs and investors, or global investment)

(4) Green (e.g., emphasis on Great Britain's sus- 
tainability and environmental protection efforts) (5) Heritage (e.g., focus on British royalty, museums, and historical landmarks)

(6) Innovation (e.g., discussion of science and technology in Great Britain)

(7) Knowledge (e.g., portrayals of research and development at British universities)

(8) Music (e.g., mentions of British and music artists)

(9) Shopping (e.g., emphasis on British shopping venues such as London as shopping city)

(10) Sport (e.g., emphasis on sporting events or athletes, such as David Beckham)

(11) Technology (e.g., focus on digital media, ecommerce, and IT services in Great Britain)

Scales: Nominal

Reliability: Krippendorf's alpha $=.90$

\section{REFERENCES}

McCombs, M. E., \& Shaw, D. L. (1972). The Agenda-Setting Function of Mass Media. Public Opinion Quarterly, 36(2), 176-187.

Zhou, S., Shen, B., Zhang, C., \& Zhong, X. (2013). Creating a Competitive Identity: Public Diplomacy in the London Olympics and Media Portrayal. Mass Communication \& Society, 16(6), 869-887. 